\title{
Recognising an STC liability versus recognising a deferred tax asset for unused STC credits according to the IASB framework: a comparison
}

ER Venter

Department of Accounting University of Pretoria
M Stiglingh

Department of Taxation University of Pretoria

\begin{abstract}
South African companies have, in the past, not recognised an asset for unused Secondary Tax on Companies ("STC") credits. AC 501, Accounting for "Secondary Tax on Companies (STC)", which is effective for annual periods beginning on or after 1 January 2004, now requires South African companies to recognise a deferred tax asset for unused STC credits, to the extent that it is probable that an entity will declare dividends of its own, against which the unused STC credits can be utilised. In terms of AC 501 and IAS 12 (AC 102), Income Taxes (the local and international accounting standard on income taxes), the recognition of a liability to pay STC has to be postponed until the declaration of a dividend. Some accounting commentators have indicated that they find it anomalous to recognise a deferred tax asset in respect of unused STC credits, while no liability is recognised for the STC that would be payable on the future distribution of retained earnings.

The objective of the study is to consider whether it is conceptually anomalous to recognise a deferred tax asset for unused STC credits while no liability is raised for the STC that would become payable on future dividend declarations on profits already recognised in the financial statements.

The study concludes that it is conceptually anomalous to recognise a deferred tax asset for unused STC credits when no corresponding liability is raised.
\end{abstract}

\section{Key words}

AC 501

AC 303

Dividends

IAS 12 (AC 102)

Secondary Tax on Companies

Unused Secondary Tax on Companies credits 


\section{Background and formulation of the study}

\subsection{Background}

In his monthly column 'Straight Talking' in Accountancy SA, Hattingh (2004:32), a wellknown Chartered Financial Analyst, comments that it is fascinating to see how differently accountants react to a situation. He describes five typical reactions to changes in accounting standards: the sheep syndrome (follows without questioning), the puppy dog syndrome (sees the good in everything, so does not criticise), the meerkat syndrome (becomes a master at ducking and diving), the hyena syndrome (finds everything hysterical) and the Rottweiler syndrome (goes for the throat - the standard is clearly wrong).

A recent change to the accounting treatment for unused Secondary Tax on Companies (STC) credits has also received some mixed reactions, varying from the 'sheep syndrome' to the 'Rottweiler syndrome'. This change in the accounting treatment for unused STC credits came at a time when significant developments were taking place in the international accounting sphere, as well as when South Africa was harmonising completely with the International Financial Reporting Standards (IFRSs).

Since 1993, South Africa has been harmonising SA GAAP with international standards (SAICA 2004a:§01). In the last few years, SA GAAP has substantially been harmonised with the IFRSs (SAICA 2003b:1). After all the convergence projects, for annual periods beginning on or after 1 January 2005, SA GAAP is an exact replica of the relevant IFRS. To indicate this, a dual numbering system is used to refer both to the IFRS and SA GAAP number (SAICA 2004b:§06). The Accounting Practices Board (APB) in South Africa has taken a decision to issue the international text of any IFRS document in South Africa without any amendments in future (SAICA 2003b:1).

The APB is committed to issuing IFRSs in South Africa without any amendments, but, in certain instances, an IFRS may need to be interpreted for specific aspects, transactions or other issues that occur only in the South African environment, as such aspects, transactions or other issues are not specifically or clearly addressed in the IFRS, as is stated in $A C 500$, Preface to South African statements and interpretations of generally accepted accounting practice (SAICA 2003c: $\$ 02)$. The AC 500 series will therefore be used in South Africa to address matters specific to South Africa and not addressed in IFRS documents (SAICA 2003a:\$07). As SA GAAP is fully aligned with IFRS, the only difference between SA GAAP and IFRS will thus be the $A C 500$ series, for which there is no IFRS equivalent. The first $A C 500$ interpretation in South Africa is AC 501, Accounting for 'Secondary Tax on Companies (STC)' (AC 501) (SAICA 2003d). AC 501 is an interpretation of the accounting for STC in South Africa based on the principles contained in IAS 12, Income Taxes (IASB 2000), the IFRS which sets out the accounting treatment for income taxes (SAICA 2003d:\$21). Companies listed on the JSE in South Africa are required to prepare financial statements in accordance with IFRS (SAICA 2003a: $\$ 03$ ). They can therefore only claim full compliance with IFRS if $A C 501$ is an accurate interpretation of the IFRS provisions. Some accounting commentators have already questioned whether $A C 501$ is fully in line with IFRS (Basson 2002:2; KPMG 2004:2; SAICA 2004c:19).

Prior to $A C$ 501, South African companies did not recognise a deferred tax asset for unused STC credits - a local accounting opinion, AC 303, Accounting for secondary tax on companies (SAICA 1999) considered these credits to be contingent assets which should 
only be disclosed in the financial statements (SAICA 1999:§09). At present, $A C 501$ (SAICA 2003d:§14) requires South African companies to recognise a deferred tax asset for unused STC credits to the extent that it is probable that the entity with the STC credit will declare dividends of its own against which unused STC credits can be used. $A C 303$ was withdrawn with the issue of $A C 501$.

This change to the accounting treatment for unused STC credits has received mixed reactions. Some believe it is anomalous to recognise a deferred tax asset in respect of unused STC credits, while no liability is recognised for the STC that would be payable on the future distribution of retained earnings (KPMG 2004:3). Vorster, Koornhof, Oberholster and Koppeschaar (2004:68) believe that the treatment of recognising a deferred tax asset for unused STC credits, while no deferred tax liability is recognised for STC, may be 'somewhat confusing'.

Paragraph 52B of IAS 12 (AC 102), Income Taxes (IASB 2000), the local and international accounting standard dealing with income taxes, determines that the income tax consequences of dividends are not recognised until a dividend has been declared. Consequently, $A C 501$ determines that the liability for STC is only recognised once a dividend declaration has occurred (SAICA 2003d:\$09). In a recent study by Venter and Stiglingh (2005:32), the majority of respondents replying to a questionnaire regarding the accounting treatment for the liability for STC agreed that the liability for STC should not be recognised until the declaration of a dividend has occurred, because prior to this date no obligating event exists on the part of the entity to distribute the profits. Venter and Stiglingh's (2005) study appears to bear out the comments made by Vorster et al. (2004:68), because the empirical results from Venter and Stiglingh's (2005) study show support for the IFRS requirements with regard to recognising an STC liability only when a dividend is declared, while the requirement of $A C 501$ to recognise a deferred tax asset for unused STC credits, prior to the declaration of a dividend, might create a 'somewhat confusing' accounting anomaly.

As the $A C 500$ series is supposed to be an interpretation of an IFRS (SAICA 2003c: $\S 02$ ), the first consideration would be to determine whether the requirement of $A C 501$ to recognise a deferred tax asset for unused STC credits (to the extent that it is probable that the entity will declare dividends of its own against which the credits could be used) is an accurate interpretation of the relevant IFRS dealing with income taxes, namely IAS 12 (IASB 2000).

The 1989 Framework for the Preparation and Presentation of Financial Statements of the IASB (the IASB Framework) sets out the concepts that underlie the preparation and presentation of financial statements for external users (IASB 1989:§01).

Amongst other things, the purpose of the IASB Framework is to assist those who prepare financial statements in applying IFRSs (SA GAAP has been fully aligned with IFRSs) and in dealing with topics that have yet to form the subject of IFRSs (IASB 1989:§01(d)). Although accounting for STC has been addressed locally by $A C$ 501, it has not yet formed the subject of an IFRS, and consequently the IASB Framework should also be used in the evaluation of issues relating to the recognition of STC.

The purpose of the IASB Framework is also to assist the IASB ('the Board') in the development of future standards and in its review of existing IFRSs (IASB 1989: §01(a)). IAS 12 (IASB 2000) is an existing IFRS referred to in this article. 
The Board recognises that in a limited number of cases there may be a conflict between the IASB Framework and an IFRS, and in these cases the requirements of the IFRS prevail over those of the IASB Framework (IASB 1989:§03). However, the Board is guided by the $I A S B$ Framework in the development of future standards and in its review of existing standards. Therefore, the number of conflicting cases between the IASB Framework and IFRSs will diminish over time (IASB 1989:§03). From this, one may conclude that ultimately the Board intends that all IFRSs should conform to the IASB Framework. Therefore, even though it is an immediate requirement for $A C 501$ to conform to the principles of $I A S 12$, ultimately $A C 501$ and $I A S 12$ should also conform to the principles of the IASB Framework.

\subsection{Objective of the study}

The objective of this study was to consider whether it is anomalous to recognise a deferred tax asset for unused STC credits prior to the declaration of a dividend while no corresponding liability for STC is recognised. This was only considered in terms of the IASB Framework.

\subsection{Research methodology}

Both a literature study and an empirical study were performed. Firstly, some background is provided on STC (Section 2 of this article). Thereafter, the problem identified in this study is investigated in the context of the principles of the IASB Framework (Section 3). The results of the literature study were then tested with a questionnaire to the partners specialising in technical accounting matters and the leading tax partners at the eight largest auditing firms in South Africa, Accounting lecturers teaching at the post-graduate level at various universities in South Africa and other relevant accounting specialists (Section 4). A conclusion is presented in Section 5 of this article.

\section{Background to STC}

A dual tax system was introduced for companies in South Africa in 1993. The aim was to encourage growth in new and fast-growing companies without prejudicing the fiscus significantly. The introduction of this system has been described as one of the more interesting developments of the 1993 budget (Old Mutual 1993:3). The announcement of a dual tax system for companies and close corporations in South Africa resulted in a reduction of the corporate tax rate, at that stage from $48 \%$ to $40 \%$, and introduced a new STC at a rate of $15 \%$ on net dividends declared by a company on or after 17 March 1993 (Business Day 1993:2). The STC rate was reduced further, to 12.5\%, as of 13 March 1996 (Department of Finance 1996:5.6). The corporate tax rate for years of assessment ending from 1 April 2005 is 29\% (National Treasury 2005:26).

In accordance with the Income Tax Act 58 of 1962 (South Africa 1962), referred to as 'Act' hereinafter, the amount of STC is based on the 'net amount' (section 64B(2) of the Act). The net amount is the amount by which the amount of dividends declared (which is not exempt from STC in terms of section $64 \mathrm{~B}(5)$ of the Act) exceeds the sum of certain dividends that accrued to the company during the dividend cycle (section $64 \mathrm{~B}(3)$ of the Act). Where the sum of dividends accrued exceeds the dividend declared (this results in unused STC credits), the excess must be carried forward and deemed to be a dividend 
which accrued to the company during the succeeding dividend cycle of the company (section 64B(3)(a) of the Act).

$A C 501$ (SAICA 2003d:§14) determines that an entity should recognise a deferred tax asset for unused STC credits to the extent that it is probable that the entity with the STC credit will declare dividends of its own, against which unused STC credits can be utilised. $A C 501$ (SAICA 2003d) does not include a definition of 'unused STC credits', but $A C 501$ (SAICA 2003d:\$21) does indicate that an 'unused STC credit' is an unused tax credit as envisaged by $I A S 12$ (IASB 2000). While $I A S 12$ (IASB 2000) does not define 'unused tax losses' or 'unused tax credits', IAS 12 (IASB 2000§05) does contain a definition of a 'tax loss', namely the loss for the period (determined in accordance with the rules established by the relevant taxation authorities) for which income taxes are recoverable. One could therefore argue that an 'unused tax loss' would mean a 'tax loss' that has not been used against taxable income.

A 'tax loss' is determined in accordance with the rules established by the relevant taxation authorities. Hence, an 'unused tax loss' must also be determined in accordance with the rules established by those taxation authorities. This implies that, in South Africa, those rules are the Act. Although IAS 12 does not define 'unused tax credits', it prescribes a similar treatment for unused tax credits as that applied for unused tax losses (IASB 2000:§34). This might indicate that for the purposes of IAS 12 (IASB 2000), an 'unused tax credit' is a credit determined in accordance with the rules established by the local taxation authority. By implication, because an unused STC credit in terms of $A C 501$ (SAICA 2003d) is considered to be an unused tax credit in terms of IAS 12 (IASB 2000), the meaning of 'unused STC credits' in $A C 501$ (SAICA 2003d) may be interpreted to be unused STC credits as determined in accordance with section 64B(3)(a) of the Act.

\section{Deferred tax asset on unused STC credits}

\subsection{Introduction}

In Section 1.1 of this article, the IASB Framework was identified as an appropriate accounting framework that could form a context for a comparison between recognising a liability for STC and recognising an asset for unused STC credits for accounting purposes. In this section, this comparison is made with reference to the IASB Framework.

\subsection{Background to the issue}

Van Blerck (2003:4) maintains that as IAS 12 (IASB 2000:§52A) currently stands, with deferred tax measured at the rate applicable to undistributed profits, one is precluded from providing for an STC liability on undistributed profits. It would therefore be inconsistent to provide for any deferred tax assets in these circumstances. As stated above, Vorster et al. (2004:68) believe that the treatment of recognising a deferred tax asset for unused STC credits, when no deferred tax liability is recognised for STC, may be 'somewhat confusing'. Based on the identified accounting framework, these arguments need to be considered in terms of the IASB Framework.

The IASB Framework (IASB 1989: $\S 49$ and $\S 83$ ) contains both the definitions of an asset and a liability and the recognition criteria for these elements. To determine whether it is indeed 'somewhat confusing' to recognise a deferred tax asset for unused STC credits prior 
to the declaration of a dividend, while no STC liability is recognised prior to the declaration of a dividend, the various definitions of the elements and the recognition criteria require further analysis.

There are various similarities between the definition of an asset and a liability and the recognition criteria thereof, as contained in the IASB Framework. The definitions and recognition criteria are compared in Table 1, below.

Table 1 Comparison between an asset and a liability

\begin{tabular}{|c|l|l|}
\hline Element & \multicolumn{1}{|c|}{ Asset } & \multicolumn{1}{|c|}{ Liability } \\
\hline 1 & $\begin{array}{l}\text { A resource controlled by the enterprise as } \\
\text { a result of past events (IASB } \\
1989: \S 49(\mathrm{a})) .\end{array}$ & $\begin{array}{l}\text { Present obligation of the enterprise arising } \\
\text { from past events (IASB 1989:§49(b)). }\end{array}$ \\
\hline 2 & $\begin{array}{l}\text { From which future economic benefits are } \\
\text { expected to flow to the enterprise (IASB } \\
1989: \S 49(\mathrm{a})) .\end{array}$ & $\begin{array}{l}\text { The settlement of which is expected to } \\
\text { result in an outflow from the enterprise of } \\
\text { resources embodying economic benefits } \\
\text { (IASB 1989:§49(b)). }\end{array}$ \\
\hline 3 & $\begin{array}{l}\text { An asset should be recognised if it is } \\
\text { probable that any future economic benefit } \\
\text { associated with the item will flow to the } \\
\text { enterprise (IASB 1989:§83(a)). }\end{array}$ & $\begin{array}{l}\text { A liability should be recognised if it is } \\
\text { probable that any future economic benefit } \\
\text { associated with the item will flow from the } \\
\text { enterprise (IASB 1989:§83(a)). }\end{array}$ \\
\hline 4 & $\begin{array}{l}\text { And the item has a cost or value that can } \\
\text { be measured with reliability (IASB } \\
1989: \S 83(b)) .\end{array}$ & $\begin{array}{l}\text { And the item has a cost or value that can } \\
\text { be measured with reliability (IASB } \\
1989: \S 83(b)) .\end{array}$ \\
\hline
\end{tabular}

AC 501 (SAICA 2003d:§09), read together with IAS 10, Events of the Balance Sheet Date, (IASB 2003:§13), requires the liability for STC to be recognised in the same period as the related dividend is accrued as a liability (in other words, when the dividends are appropriately authorised and are no longer at the discretion of the entity). The asset for unused STC credits are recognised, in accordance with $A C 501$ (SAICA 2003d:\$14), to the extent that it is probable that the entity will declare dividends of its own against which the unused STC credits can be used (in other words, in the same period that the dividend income is earned). With so many similarities between the definition of an asset and a liability and the recognition criteria for an asset and a liability in terms of the IASB Framework, one can ask whether it is appropriate to recognise a deferred tax asset for unused STC credits before the declaration of a dividend if no STC liability is recognised prior to the declaration of a dividend.

It therefore requires further investigation to determine whether it is possible (considering the definitions of an asset and a liability and the recognition criteria in the IASB Framework), that the timing of the recognition of the STC liability and that for the recognition of a deferred tax asset for unused STC credits could differ. This matter is investigated in the next section, by analysing the various elements of the definitions of an asset and a liability and the recognition criteria.

\subsubsection{First element: Past events}

In a recent study by Venter and Stiglingh (2005:15), the authors argued that there are two potential points of view with regard to the obligating event (past event) that results in a present obligation to pay STC, namely the earning of distributable profits or the declaration of a dividend. Bugg (2004:1) believes that the obligating event required to justify recording a liability for the income tax consequences of dividends is the declaration of the payment of dividends. She argues that on the balance sheet date the payment of dividends is a future 
transaction and that it is not directly related to the past earnings. The obligating event is then the ultimate shareholders' approval of the payment of dividends (Bugg 2004:1). As long as the dividend is not approved by the enterprise's bodies, the enterprise has no obligation to pay the additional tax (Nestlé S.A. 2000:2). The empirical evidence reported in the study by Venter and Stiglingh (2005:32) showed that the respondents gave preference to the notion that the necessary past event that warrants the recognition of a liability for STC in the financial statements is the declaration of a dividend, as opposed to the earning of distributable profits. No fewer than $82 \%$ of the respondents to that empirical study believed that the past event is the declaration of a dividend. This is also the approach that is followed by IAS 12 (IASB 2000:52B), which requires the income tax consequences of dividends (STC) to be recognised in the financial statements when a liability to pay a dividend is recognised (in other words, when the dividends are appropriately authorised and no longer at the discretion of the entity) (IASB 2003:§13).

One might argue that in the case of the recognition of an asset for unused STC credits, there are also two potential points of view with regard to the past event that results in a resource being controlled by the enterprise, namely the earning of dividend income or the declaration of a dividend that results in an unused STC credit or part thereof being used. $A C 501$ (SAICA 2003d:\$14) requires entities to recognise a deferred tax asset for unused STC credits, prior to the declaration of a dividend, to the extent that it is probable that the entity will realise the benefit in the future.

Von Well (2006:3) is of the opinion that that this requirement of $A C 501$ (SAICA 2003d) implies that those who set $A C 501$ (SAICA 2003d) consider the past event that results in an asset for unused STC credits to be the earning (recognition) of dividend income that may be used against future dividend declarations. By contrast, Everingham and Watson (2000:16-38) are of the opinion that it would not be appropriate to raise an asset for unused STC credits, as the credits can only be used in the event that further dividends are declared, triggering a liability for STC by the company. The future economic benefit embodied in an asset is the potential to contribute, directly or indirectly, to future cash flows of the entity (IASB 1989:§53). The potential to contribute to the future cash flows of an entity may take the form of a capability to reduce cash outflows (IASB 1989:§53). In the case of an asset for unused STC credits, the reduction in the cash outflows takes the form of a reduction in the STC that will be paid over to the South African Revenue Service (SARS) when a dividend is declared (Von Well 2006:1). Von Well (2006:2) therefore believes that the past event that gives rise to the STC asset should coincide with the past event that gives rise to the STC liability, namely the declaration of a dividend. It is therefore unclear why $A C 501$ treats the earning of dividend income as the past event if the only way in which this recognised asset (in terms of $A C 501$ ) could be realised is with a future dividend declaration.

From the discussion above, one can conclude that some degree of uncertainty exists as to whether it is possible that the past events that warrant the recognition of a liability for STC and an asset for unused STC credits could be different. This matter is considered further as part of the empirical study reported in this article (refer to Section 4.4.3 of the article for the results of the empirical study in this regard). 


\subsubsection{Second element: Inflow/outflow of economic benefits}

The second criterion, the inflow or outflow of economic benefits, will be met for both the asset and the liability, as STC normally results in a cash outflow, thereby depleting the asset base of the entity, while unused STC credits result in a decrease of the STC expense. The IASB Framework (IASB 1989:\$53) specifically states that an item that has the capability to reduce cash flows contributes to the cash flow of an entity, thereby resulting in an inflow of economic benefits. The outflow of the economic benefits, in the case of the liability for STC, and the inflow of the economic benefits, in the case of unused STC credits, therefore occurs at the same time, namely when the STC, calculated on the 'net amount' is paid to the local revenue authority.

\subsubsection{Third element: Probability of future inflow/outflow of economic benefits}

The IASB Framework (IASB 1989:§83) requires that the probability criterion must be satisfied for the recognition of assets and liabilities. The issue that needs to be considered is whether the probability criterion in itself could result in a difference in the timing of the recognition of a liability for STC and an asset for unused STC credits; or whether this difference in timing currently only exists as a result of the fact that past events are considered to be different for the asset and the liability.

In line with the IASB Framework, AC 501 (SAICA 2003d:§14) makes the recognition of a deferred tax asset for unused STC credits dependent on the probability criterion. Thus, before an entity can recognise a deferred tax asset for unused STC credits, AC 501 (SAICA $2003 \mathrm{~d}: \$ 14)$ requires that it must be probable that the entity will declare a dividend of its own against which the unused STC credits can be utilised. If it is probable that an entity will declare a dividend of its own, one might argue that it is probable that future economic benefits will flow from the entity in the form of an STC cost.

However, Venter and Stiglingh (2005:19) argue that it should be considered that the 'probability' element of the recognition criteria ties in very closely with what is considered to be the obligating event (in the case of a liability for STC) which causes an entity to recognise a liability to pay STC. If the obligating event is the declaration of a dividend, then the 'probability' element of the recognition criterion is met, because, once a dividend has been declared, it is virtually certain that STC will be triggered. However, if the obligating event is the earning of distributable profits, determining the 'probability' element becomes more problematic, as doing so necessitates determining whether future dividend declarations are indeed probable (Basson 2002:1). One could use the same argument for an asset for unused STC credits. In other words, if the past event is the declaration of a dividend that results in an unused STC credit or part thereof being used, then the probability criterion is satisfied, because once a dividend has been declared, it is virtually certain that the entity will receive the benefit of the unused STC credit. If, however, the past event is the earning of distributable profits, the probability criterion is more difficult to determine, as doing so will require determining whether future dividend declarations are probable (as required by $A C 501$ ).

The statement in $A C 501$ (SAICA 2003d:\$14) that the asset for unused STC credits may only be recognised to the extent that it is probable that the entity will declare dividends of its own against which the unused STC credits can be used may imply that it is possible to determine the probability of future dividend declarations. Hence, it seems that the 
probability criterion could be complied with for both the asset and the liability. (See Section 4.4.4 of this article for the results of the empirical questionnaire in this regard).

\subsubsection{Fourth element: Reliable measurement}

The IASB Framework (IASB 1989:\$83) requires the measurability criterion to be satisfied for the recognition of assets and liabilities. The issue that needs to be considered is whether the measurability criterion in itself could result in a difference in the timing of the recognition of a liability for STC and of an asset for unused STC credits; or whether this difference in timing currently only exists because the past events are considered to be different for the asset and the liability.

Venter and Stiglingh (2005:22) argue that the 'reliable measurement' element of the recognition criteria is also very closely linked to what is considered to be the obligating event that causes an entity to recognise a liability to pay STC. If the obligating event is the declaration of a dividend, the 'reliable measurement' element of the recognition criteria is met, because the amount of the dividend is known and, therefore, because the amount of the STC liability can be measured reliably. However, if the obligating event is the earning of distributable profits, the 'reliable measurement' element is more difficult to establish, as it necessitates an estimation of the amounts of future dividends to be declared. One could argue the same for an asset for unused STC credits. In other words, if the past event is the declaration of a dividend that results in an unused STC credit or part thereof being utilised, then the measurability criterion is satisfied. This is so because, once a dividend has been declared, the amount of the unused STC credit that will be used is known. However, if the past event is the earning of distributable profits, the measurability criterion becomes more difficult to determine, as doing so will require an estimation of the amount of unused STC credits that will be used in future.

Watson (2002:2) is of the opinion that if a company has a standard dividend cover, or if the dividend is declared prior to the finalisation of the financial statements, the recognition criteria of probability and measurability are satisfied. Hattingh (2000:2) holds a similar view: he believes that the declaration of the dividend after the year-end is an event after the balance sheet date that confirms that the company indeed had a liability for STC at the year-end on the part of the profit declared as a dividend.

All the information available up to the date of the authorisation of the financial statements should be taken into account in measuring the amount of the liability (Everingham \& Watson 2000:16-37). Everingham and Watson (2000:16-37) are of the opinion that if STC relates to profits, it should be recognised as an expense in the same year as the profits are recognised. Any post balance sheet declaration of a dividend should be used as a basis for measuring the amount of the liability. Thus, it follows that it may be possible to measure the amount of future dividend declarations reliably, and thereby the liability for STC, on the balance sheet date, although no dividend declaration has occurred by that date. If the liability for STC can in fact be measured reliably, it should also be possible to measure the amount of the asset for unused STC credits reliably. In the case of the asset, the amount of the unused STC credits will be known (as the dividend income has been earned), but this would not entitle an entity to recognise the full amount of the unused STC credit as an asset, because the full amount might not necessarily be used against dividend declarations in future. (See Section 4.4.5 of this article for the results of the empirical questionnaire in this regard).

Meditari Accountancy Research Vol.14 No. 1 2006: 103-120 
Another matter that needs to be considered is uncertain tax positions. Uncertain tax positions are positions taken in an income tax return or positions anticipated taken in a tobe-filed tax return and reflected in the effective tax rate in an entity's financial statements (IASB \& FASB 2005:1). IAS 12 is silent on how to deal with uncertainty over the amounts underlying deferred tax balances (IASB \& FASB 2005:1). However, this matter is under consideration as part of the IASB and FASB's joint short-term convergence project on income taxes (IASB \& FASB 2005:1). The IASB considers it appropriate to reflect uncertainty in tax positions through the measurement of the related tax asset or liability (IASB \& FASB 2005:3).

For example, IAS 12 makes no distinction between a normal company tax loss that has accrued to the company (by means of allowable expenditure actually incurred exceeding the income accrued to the company) and a tax loss that has been assessed by the SARS. Although one might argue that the tax loss legally only comes into existence once the SARS has assessed the loss, which might be a couple of months after the balance sheet date, in substance, the benefit of the tax loss has already accrued to the entity. The only matter that needs to be clarified by the SARS is whether the tax position taken by the entity in its calculation of the tax loss is legally justifiable in terms of the Act. If the entity has calculated the assessed loss on sound tax principles, the SARS can legally not dispute the existence of the tax loss. From an accounting perspective, this distinction is, therefore, not important for recognition purposes, but based on the IASB's view, it is only important for measurement purposes.

One might reach a similar conclusion in terms of the IASB Framework. The definition of an asset in the IASB Framework determines that a resource must be controlled by the entity (IASB 1989:§49(a)). The existence of the resource and whether the entity controls such a resource do not depend on whether the tax loss has been assessed by the SARS (in other words, a second event is not needed for the asset to come into existence). The only important factor that influences the existence of the asset is whether the entity has actually incurred allowable expenditure in excess of income. If that is the case, the resource exists as a result of a past event and the SARS will only confirm the measurement of the asset in its assessment.

By analogy, the same principles apply to an unused STC credit that has not yet been assessed by the SARS. This is relevant where, for example, dividends contemplated in section $64 \mathrm{~B}(3)$ of the Act have accrued to an entity since the previous dividend cycle and are available for future set-off against dividends declared. If the dividend cycle has not ended by the balance sheet date, the accrued STC credit will not have been confirmed in any assessment made by the SARS and a position would therefore have been taken that the SARS would allow the dividends accrued as a deduction against the amount of dividends declared or to be declared in future. This position would be reflected in the effective tax rate in the entity's financial statements and is an 'uncertain tax position' as defined above. From an accounting perspective, the distinction whether the credit has been assessed by the SARS or not is not relevant for recognition purposes, but may be relevant only for measurement purposes.

The IASB acknowledges that some tax positions are, however, based on unambiguous tax law and there is little uncertainty as to their ultimate sustainability based on the technical merits (IASB \& FASB 2005:2). In the case of unused STC credits, one could argue that the Act is unambiguous in its reference to the dividends that would qualify to create unused STC credits, as non-qualifying dividends are clearly listed in 
section $64 \mathrm{~B}(3 \mathrm{~A})$ of the Act. Consequently, the fact that some unused STC credits have not yet been assessed by the SARS may not affect the measurement of the deferred tax asset, as it is clear that the benefit exists.

\subsubsection{Findings on elements of the IASB Framework}

The following conclusions have been reached on the basis of the literature study:

There is some uncertainty as to whether it is possible that the past event that warrants the recognition of a liability for STC and an asset for unused STC credits can be different (Section 3.2.1 above).

The inflow/outflow of future economic benefits criterion will be satisfied for both a liability for STC and an asset for unused STC credits (Section 3.2.2 above).

The probability criterion can be complied with for both the liability for STC and the asset for unused STC credits prior to the declaration of a dividend (Section 3.2.3 above).

The measurability criterion can be satisfied for both the liability for STC and the asset for unused STC credits prior to the declaration of a dividend (Section 3.2.3 above).

Considering the above, it appears as though there might be some uncertainty as to whether it is appropriate that the timing of the recognition of the liability for STC and the timing of the recognition of an asset for unused STC credits are different. The next section provides details of the empirical evidence that was obtained in an attempt to clarify this uncertainty.

\section{Results of the empirical study}

\subsection{Background to the questionnaire}

The purpose of the questionnaire was to test the conclusions reached in the literature study against the opinions of accounting and tax specialists in South Africa.

The questionnaire was distributed to Accounting lecturers teaching students at the postgraduate level at South African universities, the partners specialising in technical accounting matters at the eight largest auditing firms in South Africa and the leading tax partners at the eight largest auditing firms in South Africa. These three groups form the defined population for this study. The questionnaires were sent to these focused target groups in an attempt to increase the quality of the answers. Accounting lecturers and the partners specialising in technical accounting matters were chosen as they are currently actively involved with accounting standards on a day-to-day basis and should have in-depth knowledge of the accounting requirements. The leading tax partners were chosen as they should have in-depth knowledge of STC. All three target groups should be aware of STC and the accounting for STC and should be competent to answer the questionnaire, although the tax partners were expected to have some difficulty in answering detailed accounting questions. Moreover, the limitations associated with questionnaires should be borne in mind: the answers were mainly based on the opinions and perceptions of the respondents.

The Accounting lecturers teaching at the post-graduate level at universities in South Africa were identified either from information contained on the websites of the respective universities or from a telephone call made directly to the university concerned to obtain the information and the lecturers' contact details.

The eight largest auditing firms in South Africa were identified on the basis of fee income, as contained in a survey done by the International Accounting Bulletin (Dayasena

Meditari Accountancy Research Vol.14 No. 1 2006: 103-120 
2003:12). A questionnaire was sent to the leading corporate tax partner of each identified firm and all the technical accounting partners of each firm of those firms. These individuals were identified by means of a telephone call to the firms to obtain the names and e-mail addresses of the relevant parties. Where a firm did not have a specialist accounting and/or tax department, the questionnaire was sent to the contact partner listed in the International Accounting Bulletin (Dayasena 2003:15), with a request to forward it to the most appropriate individual in the firm. The questionnaires were distributed to the parties by email.

The first part of the questionnaire presented general background on the topic and the questionnaire, while the second part consisted of general questions about the profile of the respondent. The third part contained one question relating to the status of the IASB Framework (see Section 4.4.1 of this article). The fourth part contained four questions on the application of the IASB Framework to unused STC credits (see Sections 4.4.2 to 4.4.5). The final question relates to the timing of the recognition of a liability for STC and an asset for unused STC credits (see Section 4.4.6).

\subsection{Response rate}

In total, 64 questionnaires were distributed - 33 to Accounting lecturers, 18 to accounting technical partners at the eight largest auditing firms in South Africa, seven to leading tax partners at the eight largest auditing firms in South Africa and six to other relevant accounting specialists.

The response rate in the various categories is set out in Table 2 (below).

Table 2 Response rate

\begin{tabular}{|l|c|c|}
\hline & $\begin{array}{c}\text { Actual number of } \\
\text { responses }\end{array}$ & $\begin{array}{c}\text { Response rate } \\
\%\end{array}$ \\
\hline Accounting lecturers & 16 & 48 \\
\hline Technical accounting partners & 12 & 67 \\
\hline Tax partners & 2 & 29 \\
\hline Other & 2 & 33 \\
\hline Total response & $\mathbf{3 2}$ & $\mathbf{5 0}$ \\
\hline
\end{tabular}

Questionnaires that were not completed by the deadline were followed up with additional emails and/or telephone calls.

In addition to the above, the questionnaire was forwarded to SAICA with a request to send it to all the APB and Accounting Practice Committee (APC) members. An additional two responses were obtained through this process.

For the purposes of analysis, the responses of the 'other' category and the additional two responses were grouped with the responses of the technical accounting partners, as these responses all come from accounting specialists.

\subsection{Profile of respondents}

The profile of the respondents was the following:

$38 \%$ of the respondents have less than five years experience in their particular field,

$38 \%$ have between five and ten years experience and $24 \%$ have more than ten years experience; 
$29 \%$ of the respondents considered their knowledge of section 64B of the Act as 'good', $50 \%$ considered it to be 'fair', while $21 \%$ considered their knowledge to be 'poor';

$76 \%$ of the respondents considered their knowledge of $A C 501$ to be 'good', $18 \%$ considered it to be 'fair', while $6 \%$ considered their knowledge to be 'poor'; and

$79 \%$ of the respondents considered their knowledge of IAS 12 as 'good', $15 \%$ considered it to be 'fair', while $6 \%$ considered their knowledge to be 'poor'.

\subsection{Statistical summary of results}

The tables below set out the results on the responses received to the questionnaire.

4.4.1 Do you agree that the recognition of an asset or liability for STC as either normal or deferred tax should be consistent with the principles contained in the IASB Framework for the Preparation and Presentation of Financial Statements ('the Framework')?

Table 3 Results of question 4.4.1

\begin{tabular}{|l|c|c|c|c|}
\hline & $\begin{array}{c}\text { Lecturers } \\
(\mathbf{n = 1 6 )}\end{array}$ & $\begin{array}{c}\text { Technical } \\
(\mathbf{n = 1 6 )}\end{array}$ & $\begin{array}{c}\text { Tax partners } \\
(\mathbf{n = 2})\end{array}$ & $\begin{array}{c}\text { Total } \\
(\mathbf{n = 3 4 )}\end{array}$ \\
\hline & $\mathbf{\%}$ & $\mathbf{\%}$ & $\mathbf{\%}$ & $\mathbf{\%}$ \\
\hline Totally disagree & 0 & 0 & 0 & 0 \\
\hline Disagree & 0 & 0 & 0 & 0 \\
\hline Neutral & 0 & 0 & 50 & 3 \\
\hline Agree & 44 & 25 & 50 & 35 \\
\hline Totally agree & 56 & 75 & 0 & 62 \\
\hline Total & $\mathbf{1 0 0}$ & $\mathbf{1 0 0}$ & $\mathbf{1 0 0}$ & $\mathbf{1 0 0}$ \\
\hline
\end{tabular}

The results of the questionnaire confirmed the conclusion drawn from the literature study (see Section 1.4 above), namely that principles contained in accounting standards should be in conformity with the IASB Framework. A high percentage (97\%) of the respondents agreed or totally agreed that the recognition of an asset or liability for STC should be consistent with the principles contained in the IASB Framework.

\subsubsection{What do you consider to be the 'past event' that results in a 'present obligation' for STC?}

Table 4 Results of question 4.4.2

\begin{tabular}{|l|c|c|c|c|}
\hline & $\begin{array}{c}\text { Lecturers } \\
(\mathbf{n = 1 6 )}\end{array}$ & $\begin{array}{c}\text { Technical } \\
(\mathbf{n = 1 6 )}\end{array}$ & $\begin{array}{c}\text { Tax partners } \\
(\mathbf{n = 2})\end{array}$ & $\begin{array}{c}\text { Total } \\
(\mathbf{n = 3 4})\end{array}$ \\
\hline & $\mathbf{\%}$ & $\mathbf{\%}$ & $\mathbf{\%}$ & $\mathbf{\%}$ \\
\hline The declaration of dividend & 81 & 81 & 100 & 82 \\
\hline $\begin{array}{l}\text { The recognition of } \\
\text { distributable profits }\end{array}$ & 13 & 13 & 0 & 12 \\
\hline Other & 6 & 6 & 0 & 6 \\
\hline Total & $\mathbf{1 0 0}$ & $\mathbf{1 0 0}$ & $\mathbf{1 0 0}$ & $\mathbf{1 0 0}$ \\
\hline
\end{tabular}

The majority of the respondents (82\%) agreed with the conclusions drawn from the literature study that the declaration of the dividend is the necessary past event that warrants the recognition of a liability for STC (see Section 3.2.1 of the article). 
4.4.3 If the 'past event' for the recognition of the STC liability is the declaration of a dividend, the 'past event' for the recognition of an asset for unused STC credits should be the same. Do you agree with this statement?

Table 5 Results of question 4.4.3

\begin{tabular}{|l|c|c|c|c|}
\hline & $\begin{array}{c}\text { Lecturers } \\
(\mathbf{n = 1 6})\end{array}$ & $\begin{array}{c}\text { Technical } \\
(\mathbf{n = 1 6 )}\end{array}$ & $\begin{array}{c}\text { Tax partners } \\
(\mathbf{n = 2})\end{array}$ & $\begin{array}{c}\text { Total } \\
(\mathbf{n = 3 4 )}\end{array}$ \\
\hline & $\mathbf{\%}$ & $\mathbf{\%}$ & $\boldsymbol{\%}$ & $\mathbf{\%}$ \\
\hline Totally disagree & 6 & 0 & 0 & 3 \\
\hline Disagree & 6 & 19 & 0 & 12 \\
\hline Neutral & 13 & 13 & 50 & 15 \\
\hline Agree & 63 & 13 & 50 & 38 \\
\hline Totally agree & 6 & 50 & 0 & 26 \\
\hline $\begin{array}{l}\text { Question not answered by } \\
\text { respondent }\end{array}$ & 6 & 6 & 0 & 6 \\
\hline Total & $\mathbf{1 0 0}$ & $\mathbf{1 0 0}$ & $\mathbf{1 0 0}$ & $\mathbf{1 0 0}$ \\
\hline
\end{tabular}

A high percentage of $82 \%$ of the respondents believe that the past event that results in a present obligation for STC is the declaration of a dividend (see Section 4.4.2 above). The results obtained from the empirical study confirm the conclusion drawn from the literature study (see Section 3.2.1 above): 64\% of the respondents agreed or totally agreed that if the 'past event' for the recognition of a STC liability is the declaration of a dividend, the same event should trigger the recognition of the deferred tax asset for unused STC credits. This indicates that the respondents believe that the past event for the recognition of a liability for STC and an asset for unused STC credits could not be different events - this is in line with the conclusion reached by Everingham and Watson (2000:16-38).

4.4.4 AC 501\$14 states that a deferred tax asset for unused STC credits should be recognised to the extent that it is probable that the entity will declare dividends of its own against which unused STC credits can be utilised. This indicates that the probability criterion could be complied with for both the asset for unused STC credits and liability for STC prior to the declaration of a dividend. Do you agree with this statement?

Table 6 Results of question 4.4.4

\begin{tabular}{|l|c|c|c|c|}
\hline & $\begin{array}{c}\text { Lecturers } \\
(\mathbf{n = 1 6 )}\end{array}$ & $\begin{array}{c}\text { Technical } \\
(\mathbf{n}=\mathbf{1 6})\end{array}$ & $\begin{array}{c}\text { Tax partners } \\
(\mathbf{n = 2})\end{array}$ & $\begin{array}{c}\text { Total } \\
(\mathbf{n = 3 4 )}\end{array}$ \\
\hline & $\mathbf{\%}$ & $\mathbf{\%}$ & $\mathbf{\%}$ & $\mathbf{\%}$ \\
\hline Totally disagree & 0 & 31 & 0 & 15 \\
\hline Disagree & 31 & 50 & 0 & 38 \\
\hline Neutral & 6 & 6 & 50 & 9 \\
\hline Agree & 44 & 13 & 50 & 29 \\
\hline Totally agree & 6 & 0 & 0 & 3 \\
\hline $\begin{array}{l}\text { Question not answered by } \\
\text { respondent }\end{array}$ & 13 & 0 & 0 & 6 \\
\hline Total & $\mathbf{1 0 0}$ & $\mathbf{1 0 0}$ & $\mathbf{1 0 0}$ & $\mathbf{1 0 0}$ \\
\hline
\end{tabular}

Only $32 \%$ of the respondents agreed with the results obtained from the literature study (see Section 3.2.2 of this article), namely that the probability criterion could be satisfied for both 
the asset and the liability for STC prior to the declaration of a dividend. However, $50 \%$ of Accounting lecturers agreed or totally agreed that the probability criterion could be satisfied for both the asset and the liability prior to the declaration of a dividend. The inconsistent results might indicate an uncertainty as to whether the probability criterion could be satisfied prior to the declaration of a dividend.

\subsubsection{If the deferred tax asset for unused STC credits can be measured reliably} prior to the declaration of a dividend, it should also be possible to measure the amount of the liability for STC on future dividend declarations reliably. Do you agree with this statement?

Table 7 Results of question 4.4.5

\begin{tabular}{|l|c|c|c|c|}
\hline & $\begin{array}{c}\text { Lecturers } \\
(\mathbf{n = 1 6})\end{array}$ & $\begin{array}{c}\text { Technical } \\
(\mathbf{n = 1 6 )}\end{array}$ & $\begin{array}{c}\text { Tax partners } \\
(\mathbf{n = 2})\end{array}$ & $\begin{array}{c}\text { Total } \\
(\mathbf{n = 3 4})\end{array}$ \\
\hline & $\mathbf{\%}$ & $\mathbf{\%}$ & $\mathbf{\%}$ & $\mathbf{\%}$ \\
\hline Totally disagree & 6 & 44 & 0 & 24 \\
\hline Disagree & 69 & 25 & 50 & 47 \\
\hline Neutral & 0 & 6 & 0 & 3 \\
\hline Agree & 19 & 25 & 50 & 24 \\
\hline Totally agree & 6 & 0 & 0 & 3 \\
\hline Total & $\mathbf{1 0 0}$ & $\mathbf{1 0 0}$ & $\mathbf{1 0 0}$ & $\mathbf{1 0 0}$ \\
\hline
\end{tabular}

Only $27 \%$ of the respondents supported the findings of the literature study (see Section 3.3.3 above) that the measurability criterion for both the asset and liability could be satisfied on the balance sheet date even though no dividend declaration has yet occurred by that date.

\subsubsection{If a deferred tax asset is raised for unused STC credits to be utilised on} future dividend declarations, a liability should be recognised at the same time for the STC expense on the future dividend declaration. Do you agree with this statement?

Table 8 Results of question 4.4.6

\begin{tabular}{|l|c|c|c|c|}
\hline & $\begin{array}{c}\text { Lecturers } \\
(\mathbf{n = 1 6})\end{array}$ & $\begin{array}{c}\text { Technical } \\
(\mathbf{n = 1 6 )}\end{array}$ & $\begin{array}{c}\text { Tax partners } \\
(\mathbf{n = 2})\end{array}$ & $\begin{array}{c}\text { Total } \\
(\mathbf{n = 3 4 )}\end{array}$ \\
\hline & $\mathbf{\%}$ & $\mathbf{\%}$ & $\mathbf{\%}$ & $\mathbf{\%}$ \\
\hline Totally disagree & 6 & 44 & 0 & 24 \\
\hline Disagree & 63 & 38 & 50 & 50 \\
\hline Neutral & 13 & 0 & 0 & 6 \\
\hline Agree & 6 & 13 & 50 & 12 \\
\hline Totally agree & 13 & 0 & 0 & 6 \\
\hline $\begin{array}{l}\text { Question not answered by } \\
\text { respondent }\end{array}$ & 0 & 6 & 0 & 3 \\
\hline Total & $\mathbf{1 0 0}$ & $\mathbf{1 0 0}$ & $\mathbf{1 0 0}$ & $\mathbf{1 0 0}$ \\
\hline
\end{tabular}

Most of the respondents (74\%) disagreed with this statement, indicating that they do not necessarily believe that a liability for STC should be raised prior to the declaration of a dividend if a deferred tax asset for unused STC credits is raised prior to the declaration of a dividend. This indicates that the respondents do not believe that the fact that a deferred tax 
asset is recognised for unused STC credits prior to the declaration of a dividend changes the necessary past event for the recognition of a liability for STC to the earning of distributable profits, as opposed to the declaration of a dividend. In Section 4.4.2, a majority of respondents indicated that they believe that the necessary past event for the recognition of a liability for STC is the declaration of a dividend. Based on the responses to this question, the status quo remains, even if an asset is recognised for unused STC credits prior to the declaration of a dividend. The results obtained from Section 4.4.3, moreover, indicate that the respondents believe that it is inappropriate to recognise a deferred tax asset for unused STC credits until a dividend declaration resulting in an unused STC credit or part thereof being used has occurred. This would mean that the respondents believe that it is only appropriate to recognise the asset for unused STC credits and the liability for STC at the same time, namely when the dividend is declared.

\subsection{Findings of the empirical study}

The following evidence emerged from the empirical study:

Most of the respondents believed that the past event that warrants the recognition of a liability for STC and an asset for unused STC credits should be the same event, namely the declaration of a dividend (see Sections 4.4.2, 4.4.3 and 4.4.6).

There was some uncertainty among respondents as to whether the probability criterion could be satisfied for both the liability and the asset prior to the declaration of a dividend. As argued in Section 3.2.3, this will only be relevant if the past event is considered to be the earning of distributable profits. As most of the respondents believe that the past event for both the liability for STC and the asset for unused STC credits should be the declaration of a dividend, the probability criterion is satisfied for both the asset and the liability on the declaration of a dividend (see Section 3.2.3 above).

In general, the respondents did not agree that the measurability criterion could be satisfied for both the liability and the asset prior to the declaration of a dividend. As argued in Section 3.2.4, this will only be relevant if the past event is considered to be the earning of distributable profits. As most of the respondents believed that the past event for both the liability for STC and the asset for unused STC credits should be the declaration of a dividend, the measurability criterion is satisfied for both the asset and the liability on the declaration of a dividend (see Section 3.2.4 above).

\section{Conclusion}

The purpose of this study was to consider whether it is anomalous, in terms of the IASB Framework, to recognise a deferred tax asset for unused STC credits prior to the declaration of a dividend, when no liability for STC is recognised prior to the declaration of a dividend.

The answers of the majority of the respondents to the questionnaire supported the arguments of Everingham and Watson (2000:16-38) and Von Well (2006:2), as set out in the literature study (see Section 3.2.1), that the necessary past event for the recognition of a liability for STC is the declaration of a dividend and that the past event for the recognition of an asset for unused STC credits should be the same (see Section 4.4.3). The literature study supports the notion that the probability recognition criterion could be satisfied for both the asset and the liability prior to the declaration of a dividend. However, there is some uncertainty among respondents to the questionnaire about this. The results from the 
empirical study also do not support the conclusion drawn from the literature study that the measurability criterion could be satisfied for both the asset and the liability prior to the declaration of the dividend.

Even though it appears as though there is some uncertainty with regard to the probability and measurability criteria prior to the declaration of a dividend for both the asset and liability, non-compliance with the past event criterion would mean that it is inappropriate, in terms of the IASB Framework, to recognise a liability or an asset for STC prior to the declaration of a dividend. Based on the results of the empirical study (see Section 4.5 above), it appears that the respondents hold a similar view to that expressed by Everingham and Watson (2000:16-38) (see Section 3.2.1 above), namely that the past event that warrants the recognition of a liability and an asset for STC should be the same event, namely the declaration of a dividend.

The conclusion can therefore be reached that the beliefs of the majority of the respondents suggest that the consensus reached in $A C 501$ on the recognition of a deferred tax asset for unused STC credits prior to the declaration of a dividend may not be in line with the IASB Framework. Further research could focus on whether the consensus in $A C 501$ with regard to the recognition of a deferred tax asset for unused STC credits is in line with $I A S$ 12. As part of the commitment of the APB to issue IFRSs in South Africa without amendments, it is necessary to ensure that the $A C 500$-series is an accurate interpretation of IFRSs. Local interpretations of IFRSs need to be acceptable in order for financial reporting in South Africa to remain part of the global accounting arena.

\section{Bibliograhy}

Basson, L. 2002. Momentum Group. Comments to ED 159, Accounting for Secondary Tax on Companies. 19 September.

Bugg, K. (kbugg@iasb.org.uk). Information required. E-mail to Venter, E.R. (elmar.venter@up.ac.za).5 July 2004.

Business Day. 1993. Dual company tax system to promote growth, jobs, 18 March.

Dayasena, M. 2003. South Africa: a positive outlook. International Accounting Bulletin, 21 March:11-15.

Department of Finance. 1996. Budget Review 13 March 1996. Pretoria: Government Printer.

Everingham, G.K. \& Watson, A. 2000. Generally Accepted Accounting Practice - a South African viewpoint. $2^{\text {nd }}$ edition. Cape Town: Juta.

Hattingh, C. 2000. What ever happened to Good Olde Common Sense? Accountancy SA, October:27-29.

Hattingh, C. 2004. Defending the indefensible. Accounting SA, July:32-33.

International Accounting Standards Board (IASB). 1989. Framework for the Preparation and Presentation of Financial Statements. London: IASB.

International Accounting Standards Board (IASB). 2000. IAS 12, Income Taxes. London: IASB.

International Accounting Standards Board (IASB). 2003. IAS 10, Events after the Balance Sheet Date. London: IASB. 
International Accounting Standards Board \& Financial Accounting Standards Board (IASB \& FASB). 2005. Information for Observers, IASB/FASB Joint Meeting October 2005.

KPMG. 2004. AC 501 Accounting for STC. Accounting matters, March:2-3.

National Treasury. 2005. Budget Speech 2005. Pretoria: Government Printer.

Nestlé S.A. 2000. Comments to E68, Income Tax Consequences of Dividends - Proposed Limited Revisions to IAS 12 (revised 1996). 12 September.

Old Mutual. 1993. Budget Highlights 1993. Cape Town: Old Mutual Legal Services.

South Africa. 1962. The Income Tax Act, Act 58 of 1962. Pretoria: Government Printer.

South African Institute of Chartered Accountants (SAICA). 1999. AC 303, Accounting for secondary tax on companies. Johannesburg: SAICA.

South African Institute of Chartered Accountants (SAICA). 2003a. Circular 5/2003, Alignment of the text of Statements of Generally Accepted Accounting Practice with that of International Financial Reporting Standards. Johannesburg: SAICA.

South African Institute of Chartered Accountants (SAICA). 2003b. Exposure Draft 167, Alignment of text of Statements of Generally Accepted Accounting Practice with that of International Financial Reporting Standards. Johannesburg: SAICA.

South African Institute of Chartered Accountants (SAICA). 2003c. AC 500, Preface to South African statements and interpretations of generally accepted accounting practice. Johannesburg: SAICA.

South African Institute of Chartered Accountants (SAICA). 2003d. AC 501, Accounting for 'Secondary Tax on Companies (STC)'. Johannesburg: SAICA.

South African Institute of Chartered Accountants (SAICA). 2004a. Circular 7/2004, Status and effective dates of Statements of Generally Accepted Accounting Practice (GAAP) and Interpretations of Statements of GAAP. Johannesburg: SAICA.

South African Institute of Chartered Accountants (SAICA). 2004b. Exposure Draft 174, Preface to the Statements of Generally Accepted Accounting Practice. Johannesburg: SAICA.

South African Institute of Chartered Accountants (SAICA). 2004c. Techtalk Issue 100. Accountancy SA, February:19-22.

Van Blerck, M. 2003. Comments on STC and Deferred Tax. 10 November.

Venter, E.R. \& Stiglingh, M. 2005. The timing of the recognition of the income tax consequences of dividends in accordance with International Financial Reporting Standards. www.niagara.edu/ciaer/2005/documents/Fullarticleandabstract.doc. Accessed 19 December 2005.

Von Well, R. (rieka.vonwell@up.ac.za) 2006. Questions relating to AC 501: Recognition of a deferred tax asset for unused STC credits. E-mail to Venter, E.R. (elmar.venter@up.ac.za).5 May 2006.

Vorster, Q., Koornhof, C., Oberholster, J.G.I. \& Koppeschaar, Z.R. 2004. Descriptive Accounting. $8^{\text {th }}$ edition. Durban: Butterworths.

Watson, A. 2002. Associate Professor of Accounting, University of Cape Town. Comments to ED 153, Accounting for Secondary Tax on Companies. 29 April 2002. 